ISSN No. 0974-035X

An indexed refereed \& peer-reviewed journal of higher education

Towards Excellence

UGC-HUMAN RESOURCE DEVELOPMENT CENTRE

Gujarat University, Ahmedabad-380009, Gujarat, India

\title{
AN EMPIRICAL STUDY TO MEASURE CONSUMER PREFERENCES TOWARDS NUTRACEUTICALS AND DIETARY SUPPLEMENTS IN GUJARAT- NEED OF AN HOUR CONSIDERING COVID-19
}

\author{
Dr. Shah Suraj Manojkumar \\ (Prof.) Dr. Maurvi Vasavada \\ Dhruv Nitinbhai Muliya
}

\begin{abstract}
"Precaution is better than cure." Nutraceuticals industry is founded on this value which is a prevention driven model. Since Nutraceuticals and dietary supplements industry are developing significantly nowadays, but still, it is a growing industry. During covid-19 pandemic it is essential that you have to be health conscious so it can be an affect the nutraceutical market which provide consumer value they expect. Dietary supplements are the nutrients which was extracted from food on the basis of necessities. The range of products which is helpful to children, aged people by its features and outcomes which is accessible in various forms and contents. This research paper intentions to identified the awareness preference concerning this industry.
\end{abstract}

\section{Research Objective}

The persistence of the learning is to measure the factor affecting the selection of nutraceuticals and dietary supplements with reference to preference, Health consciousness and awareness.

\section{Research Methodology}

The experimental research design method for this study. Sample were chosen here is non probability convenience sampling method. Sample size is 412 . Who used or willing to use these products are considered as sample unit. Data for this study collected from primary (Collected by organized questionnaire) and secondary resources.

\section{Data Analysis}

Data analysis concludes that there is a substantial impact of the preference of the customer, health consciousness and awareness of the customer towards nutraceutical and dietary supplements.

\section{Social Implication}


Towards Excellence: An Indexed, Refereed \& Peer Reviewed Journal of Higher Education

Dr. Shah Suraj Manojkumar,(Prof.) Dr. Maurvi Vasavada \& Dhruv Nitinbhai Muliya/ Page

634-655

This research makes available the valuable insinuation to the sellers, civilization and customer by provided that more in depth insight into the product of nutraceuticals and dietary supplements.

\section{Originality/Value}

Few studies conducted in abroad and also in India but there is research gap on mentioned topic which will add more knowledge, information and provide new direction to the nutraceutical market.

Key Words: Nutraceuticals, Dietary supplements, Health consciousness, Nutrition, Covid-19.

\section{Introduction}

Contrived the term Nutraceuticals by Dr. Stephen which is amalgamation of pharmaceutical and nutrition. Passageway of the 1994 act of dietary supplement health \& education, Nutraceuticals has been expanded to incorporatedvitamins, minerals, amino acids\& other botanicals, basils, and dietary ingredient for human usage as supplement diet, which is a definition of Nutraceuticals."(bahadoran, mirmiran, \& azizi, 2013; bull, rapport, \& lockwood, 2000) "Excluding water, all foods are a mix of some micronutrients, Phyto-nutrientsand/or macronutrients and are therefore complex systems." (chaudhari, power, \& pratapwar, 2017)

From the survey in France, Germany and U.K the concept of nutraceutical was stared. which determined by consumers that food is valued more extremely than workout or genetic influences for accomplishing healthiness. Humanoid body Nutraceutical may be a term think of to explain substances which aren't conventionallyhave optimistic physiological effects but recognized nutrients. In nutraceuticals they are doing not effortlessly fall under the authorized class of nutriment, drug and sometimes reside grey area amid the antagonistic effect or Risk of toxicity of medicine which is controlled us to think about harmless functional food and nutraceuticals grounded tactics for the fitness management. During a universal nutraceutical revolution this resulted. "Author also says thatInto a replacement era of medication and health the nutraceutical rebellion will bring us, wherein the food manufacturing will developed search concerned with one parallel to the pharmaceutical industry." (das, bhaumik, raychaudhuri, \& chakraborty, 2011) "In this Contain one or more than one of the subsequent dietary elements, vitamin,mineral, herb or further botanical, amino acid, dietary ingredient for use by the people to increasing total daily intake of supplement in the diet, or a metabolite, concentrate, combinations, extract, constituent or of these components." (Wadekar, 2009)

The nutraceuticals\& functional foods advantageous effects can be determined that: cardiovascular diseasesdanger decreases, also abridged risk of cancer, weight management, better-qualityof reminiscence, abridged osteoporosis, faster reaction time, better fetal health and also reduced risk of many different types of other diseases."(jain \& ramawat, 2013) "Nutraceuticals and Functional foods will have good well-being for the civilization in future; to be beneficial it has been crediblyverified for their envisioned purposes when consumed by way of fragment of a commonlyproportionate\&wholesome diet."(jain \& ramawat, 2013) "Correspondingly, many supplementaryevidences \&informationrequirement to be accessible to assistance consumer for the accurate choosing \& using the functional foods and/or 
Towards Excellence: An Indexed, Refereed \& Peer Reviewed Journal of Higher Education

Dr. Shah Suraj Manojkumar,(Prof.) Dr. Maurvi Vasavada \& Dhruv Nitinbhai Muliya/ Page

$\underline{634-655}$

nutraceuticals to accomplish the promised health reimbursements." (jain \& ramawat, 2013) "We also can say about substances thatprovide protection against chronic diseases or have physiological benefits. Nutraceuticals might be utilized toincrease life expectancy, postponementof the aging process in normal human body, improve health, avoid chronic illnesses or provision the construction or function of the normal human body. These days, because of potential nutritional for human body, protection and therapeutic effects nutraceuticals have received considerable interest." (kalra, 2003) "Nutraceuticals make available all the essential substances that should be existing in a healthy diet for the human." (Keservani, et al., 2010) "Currently more than 470 functional food and nutraceutical products are available with standard health benefits." (R.venkataraman, 2011)This goes on: "Any combination or substance of elements which maybe serve to animals or human lives with a sight to making diagnosis of a constructive disease in body or to correcting, restoring or treatable physiological functions in animals or human which can help a lot to the nutrition science and its research which conducting continuously. Correspondingly measured a medicinal product." The product describes by this definition which has a medical function regardless of whether these entitlements have been stated or not, which would consist of numerous supplements being taken for medical purposes." (shahidi, 2012)

\section{Literature Review}

(barnes \& prasain, 2005)said that "Let food be the medicine and medicine be the food".Here the products or items of nutraceuticals are perceived and produce medical advantages like lightening the danger of malignancy and heart infection and furthermore to forestall or treat high blood pressure, high level of cholesterol in body, over the top weight,diabetes and many more disease.(prabhu, SuriyaPrakash, kumar, kumar, \& Raghavendran, 2012). (Maughan, King, \& Lea, 2003) said that, "The fact thatextensively accepted that health-promoting properties of foods are not necessarilybecause of single components which present in the food, but rather than few or more than a few active ingredients." "Today's era peoples have high interest in Nutraceuticals due to their potential nutritional present in component and safety profile provided in nutraceutical foods, also other than therapeutic capability of nutraceuticals. Pharmaceutical and nutritional companies which manufacturing the nutraceuticals or related to nutraceutical products are aware of the moving trends which are due to the beneficial advantages of these compounds. Although Utmost of the nutraceutical's products possessesmany therapeutic benefits." (nasri, baradaran, shirzad, \& kopaei, 2014). Peoples in a large proportionwants to get rid from the effects of aging, Novelconcentration on averting medicine and Civic perception and their belief that "natural is good".(radhika, rawat, \& thangavel). "A normal person's aging process of human cell which is develop continuously in human bodyis nonstop influenced by the factors like internal and external for example the biologicalevolution of human cells, ultraviolet radiation comes from sun radiation, if person have habit of tobacco, deficiencies of nutrition and also imbalance of the hormoneswhichcause to the degradation of human derma cells. Over the human derma layer cellsdegradation, free radicals present in body and swellingmade repair mechanisms system weak and outcome in fiber of elasticand collagen breakdown."(nasri, baradaran, shirzad, \& kopaei, 2014; souyoul, saussy, P, \& lupo, 2017)“"The purpose behind this study is to support or for help of dermatologists forstudy and the mechanism of action of widely used nutraceuticals and their conceivable efficacy inskin health and antiaging ." (Mishra, 2018) "Functional food 
Towards Excellence: An Indexed, Refereed \& Peer Reviewed Journal of Higher Education

Dr. Shah Suraj Manojkumar,(Prof.) Dr. Maurvi Vasavada \& Dhruv Nitinbhai Muliya/ Page

$\underline{634-655}$

and nutraceutical industry grow exponentially and also it has are anexceptionalposition amonginterest of consumer."(rajasekaran, sivagnanam, \& xavier, 2008)Administrative system of nutraceuticals in India needs consideration from the applicable specialists(Gupta, chauhan, mehla, sood, \& nair, 2010). Green tea polyphenols have been appeared to have amazing cancer prevention agent, calming, and anticancer advantages. The most celebrated of these is epigallocatechin-3-gallate (EGCG).(gupta \& prakash, 2014; laturkar, 2011) In India Changing Food habits nowadays are the serious concern"(sharma, 2017; shinde, bangar, deshmukh, \& kumbhar, 2014)“"The unenlightened, nutraceutical speaks to a developing portion of nourishments that are accepted to be stacked with common therapeutic properties, or what have come to be known as "useful nourishments." Good models incorporate red wine (a cell reinforcement) broccoli (malignancy precaution) and soy and clover that, a few scientists guarantee improves blood vessel wellbeing in ladies.”(Basak, 2011; Bajtelsmit, 1996)

The United States of America as of now has the biggest and most quickly extending useful food and nutraceutical showcase on the planet. In 2006 estimation of the business was $\$ 21.3$ billion.(basu, thomas, \& acharya, 2007) "The person who are athlete by profession or sports man are highly need of nutraceuticals products because of their wide range are goal they need the most."(Pandey, verma, \& saraf, 2010; radhika, rawat, \& thangavel) "Nowadays how health care is managed the Consumers are deeply concerned about, priced and administered. patients are irritated with the modern, expensive disease treatment and especially in modern medicine" (barnes \& prasain, 2005; Maughan, King, \& Lea, 2003; Sohaimy, 2012) "In the year of 2016, the appraisedoccurrence of Cardio Vascular Diseases in India was predictable to be approx 54.5 million. If 4 death occurs so 1 out of 4 deaths in India are now because of Cardio Vascular Diseases with ischemic heart disease \&Heart attack responsible for $>80 \%$ of this burden."(Ahmad A. Abdul-Aziz, 2019)"The percentage of overweight or obese person in India expectedly are going to $9 \%$ in 1995 to $24 \%$ in 2025 said by Scientists. With reference to Time magazine Scientists expect that by 2020, 40 million people will suffer from Osteoarthritis."(TimeMagazine, 2003)Suggestive Facts are that- "In India More than 40\% deaths can be credited to risk factors arising from nutritional imbalance."(World Health Statistics 2009, 2009; WorldBank, 2007)“'Due to deficiency of Vitamin A approx 330,000 child deaths occur every year in India."(Kotecha, 2008)

\section{Scope of The Study}

1. Scope of the study is circumscribed to Ahmedabad, Vadodara, Surat and Rajkot.

2. Researchers have taken all the age group as sampling unit. Study is restricted to Products include in Nutraceuticals and dietary supplements.

3. Further the conceptual scope of study is limited to Brand awareness, Brand image, Health Consciousness, Preference and attitude for Nutraceuticals and dietary supplements.

4. Diverse statistic components such as age, Gender, conjugal status, Education occupation, salary and family individuals are taken in to consideration.

\section{Research Gap}

Many researches have been done in India as well as abroad on Antioxidants supplements, but there is a research gap to measure the preference of customers towards 
Towards Excellence: An Indexed, Refereed \& Peer Reviewed Journal of Higher Education

Dr. Shah Suraj Manojkumar,(Prof.) Dr. Maurvi Vasavada \& Dhruv Nitinbhai Muliya/ Page

634-655

Antioxidants supplements on the relationship between Brand awareness, Image, Quality, price, Health Consciousness and preferences in Gujarat.

\section{Need of Study}

Nutraceuticals and dietary supplements are the range of products which is nourished by nutrition which necessary for a human body. Nutraceuticals are helping the people to fulfill the daily requirements of nutrition of body that's why it is a growing industry in current scenario.

In today's competitive world the people have less time to accomplish their daily requirement of nutrition also people are diverting towards junk food and street food which has poor nutrition and it cooked in oil and full of sugar also which harm our body. So, the solution is nutraceuticals and dietary supplements which accomplish nutritional need of body. This study focuses to contribute new findings to the emerging era of Nutraceuticals and dietary supplements. From the practical contributions perspective, current study focuses to provide statistical proven outcomes to marketers, doctors, healthcare experts to plan and draft strategies. If we see from the decision-makingpoint of viewalong with view point of practioners, working with corporate, society and government, this research will provide a valuable information and knowledge to same.

\section{Research Methodology}

Here the experimental research design method for this study. Sample were chosen here is non probability convenience sampling method. Here the sample size is 412 . Individual who are used or willing to used nutraceuticals and dietary supplements are considered as a sample unit. The data for this study collected from secondary sources and412respondents that is primary data collection. Here in this research study the researcher collects the primary data by the assistance of structured questionnaire. The type of research paper will be exploratory, conclusive and descriptive research where data analysis is quantitative and test the specific hypothesis.

Survey is done in four major cities of Gujarat namely Ahmedabad, Vadodara, Surat and Rajkot. Descriptive Statistics and Inferential statistics such as Anova Test, Chi-Square Test, Reliability Test, Regression Test and Mean Test is applied using SPSS

\section{Objectives of Study}

- To study preference of consumers for the Nutraceuticals dietary supplements.

- To know the Health consciousness of people.

- To study the awareness level of people towards Nutraceuticals dietary supplements.

\section{Research Instrument}

Here researcher used structured questionnaire having close ended questions with Noncomparative scaling techniques used in this study. In this non-comparative scale Researcher used Likert scale like, $1=$ strongly disagree to $5=$ strongly agree.

By the help of Structured questions: multiple choice and Likert scale.

\section{Construct us in study}


Towards Excellence: An Indexed, Refereed \& Peer Reviewed Journal of Higher Education $\angle D r$. Shah Suraj Manojkumar,(Prof.) Dr. Maurvi Vasavada \& Dhruv Nitinbhai Muliya/ Page $\underline{634-655}$

\begin{tabular}{|l|l|l|l|}
\hline Sr.No. & Author name & Year & Variables \\
\hline 1 & $\begin{array}{l}\text { Teoh, Ngorsuraches, Ming Lai, Bangpan, \& } \\
\text { Chaiyakunapruk }\end{array}$ & 2020 & Price \\
\hline 2 & $\begin{array}{l}\text { Teoh, Ngorsuraches, Ming Lai, Bangpan, \& } \\
\text { Chaiyakunapruk }\end{array}$ & 2018 & Quality / Safety \\
\hline 3 & Banerjee & 2018 & Brand preference \\
\hline 4 & shinde, bangar, deshmukh, \& kumbhar & 2014 & Packaging / Labelling \\
\hline 5 & Fardet & 2015 & Health consciousness \\
\hline 6 & $\begin{array}{l}\text { cicero \& colletti } \\
\text { Mehta \& Huynh-ba }\end{array}$ & 2017 & $\begin{array}{l}\text { Awareness } \\
\text { advertisement }\end{array}$ \\
\hline 7 & dureja, kaushik, \& kumar & 2003 & Shelf-life \\
\hline 9 & $\begin{array}{l}\text { Teoh, Ngorsuraches, Ming Lai, Bangpan, \& } \\
\text { Chaiyakunapruk }\end{array}$ & 2018 & Ease of purchasing \\
\hline 10 & Cardello.Armand \& Schutz & 2003 & Taste and acceptability \\
\hline
\end{tabular}

\section{Data Analysis}

\section{Respondent's Profile}

\begin{tabular}{|l|l|l|l|l|}
\hline Factors & Particulars & Frequency & Percent & $\begin{array}{l}\text { Cumulative } \\
\text { Percent }\end{array}$ \\
\hline \multirow{5}{*}{ Gender } & Male & 283 & 68.7 & 68.7 \\
\cline { 2 - 5 } & Female & 129 & 31.3 & 100 \\
\cline { 2 - 5 } & Total & 412 & 100 & \\
\hline \multirow{5}{*}{ Age Group } & $18-28$ & 98 & 23.78 & 23.78 \\
\cline { 2 - 6 } & $29-38$ & 93 & 22.57 & 46.35 \\
\cline { 2 - 6 } & $39-48$ & 81 & 19.66 & 66.01 \\
\cline { 2 - 6 } & $49-58$ & 92 & 22.33 & 88.34 \\
\cline { 2 - 5 } & Above 58 & 48 & 11.66 & 100 \\
\cline { 2 - 5 } & Total & 412 & 100 & 79.13 \\
\hline Marital Status & Married & 326 & & \\
\hline
\end{tabular}


Towards Excellence: An Indexed, Refereed \& Peer Reviewed Journal of Higher Education Dr. Shah Suraj Manojkumar,(Prof.) Dr. Maurvi Vasavada \& Dhruv Nitinbhai Muliya/ Page 634-655

\begin{tabular}{|c|c|c|c|c|}
\hline & Unmarried & 86 & 20.87 & 100 \\
\hline & Total & 412 & 100 & \\
\hline Education & $\begin{array}{l}\text { No formal } \\
\text { education }\end{array}$ & 10 & 2.4 & 2.4 \\
\hline & $\begin{array}{l}\text { Up to higher } \\
\text { secondary }\end{array}$ & 40 & 9.7 & 12.1 \\
\hline & Diploma & 25 & 6.1 & 18.2 \\
\hline & Graduation & 235 & 57.0 & 75.2 \\
\hline & $\begin{array}{l}\text { Post-graduation } \\
\text { and above }\end{array}$ & 102 & 24.8 & 100 \\
\hline & Total & 412 & 100 & \\
\hline Occupation & Student & 97 & 23.54 & 23.54 \\
\hline & Home maker & 33 & 08.00 & 31.54 \\
\hline & Self employed & 62 & 15.04 & 46.58 \\
\hline & Salaried & 108 & 26.21 & 72.79 \\
\hline & Business & 112 & 27.21 & 100 \\
\hline & Total & 412 & 100 & \\
\hline Annually & Below $2,00,000$ & 87 & 21.1 & 21.1 \\
\hline Famiry income & $\begin{array}{l}2.00,001- \\
4,00,000\end{array}$ & 94 & 22.8 & 43.9 \\
\hline & $\begin{array}{l}4,00,001- \\
6,00,000\end{array}$ & 78 & 18.9 & 62.9 \\
\hline & $\begin{array}{l}6,00,001- \\
8,00,000\end{array}$ & 63 & 15.3 & 78.2 \\
\hline & $\begin{array}{l}8,00,001- \\
10,00,000\end{array}$ & 52 & 12.6 & 90.8 \\
\hline & $\begin{array}{l}\text { Above } \\
10,00,000\end{array}$ & 38 & 9.2 & 100 \\
\hline & Total & 412 & 100 & \\
\hline
\end{tabular}


Towards Excellence: An Indexed, Refereed \& Peer Reviewed Journal of Higher Education $\angle D r$. Shah Suraj Manojkumar,(Prof.) Dr. Maurvi Vasavada \& Dhruv Nitinbhai Muliya/ Page 634-655

\begin{tabular}{|l|l|l|l|l|}
\hline \multirow{3}{*}{$\begin{array}{l}\text { Mamily } \\
\text { Members }\end{array}$} & $1-2$ & 24 & 5.8 & 5.8 \\
\cline { 2 - 5 } & $3-4$ & 248 & 60.2 & 66.0 \\
\cline { 2 - 5 } & $5-6$ & 117 & 28.4 & 94.4 \\
\cline { 2 - 5 } & More than 6 & 23 & 5.6 & 100 \\
\cline { 2 - 5 } & Total & 412 & 100 & \\
\hline
\end{tabular}

\section{Reliability Test}

\begin{tabular}{|l|l|l|}
\hline Cronbach's Alpha & $\begin{array}{l}\text { Cronbach's Alpha Based on } \\
\text { Standardized Items }\end{array}$ & N of Items \\
\hline .950 & .953 & 39 \\
\hline
\end{tabular}

Conferring to reliability analysis, Cronbach's is 0.950 , so the data is reliable for the further studies.

\section{Mean Test}

\begin{tabular}{|l|c|c|c|}
\hline Particulars & $\mathbf{N}$ & Mean & Std. deviation \\
\hline Price - Affordable price & 412 & 4.2184 & .92589 \\
\hline Price - Rate product in terms of price & 412 & 3.9393 & 1.04344 \\
\hline Price - Inexpensive product & 412 & 3.7985 & 1.15077 \\
\hline Price - Value for money & 412 & 4.1262 & .99321 \\
\hline Price - Conscious towards low price & 412 & 3.6359 & 1.20964 \\
\hline Brand - Brand name while purchasing & 412 & 3.9830 & 1.02390 \\
\hline Brand - Known brand & 412 & 4.0995 & 1.00959 \\
\hline Brand - Well-known brand is first priority & 412 & 4.1553 & .86576 \\
\hline Quality - Quality over price & 412 & 4.3869 & .73499 \\
\hline Quality - Quality is better than other brands & 412 & 4.4150 & .74486 \\
\hline Quality - Repurchase on basis of quality & 412 & 4.4248 & .75240 \\
\hline Packaging - Attractive packaging & 412 & 3.7718 & 1.08804 \\
\hline
\end{tabular}


Towards Excellence: An Indexed, Refereed \& Peer Reviewed Journal of Higher Education Dr. Shah Suraj Manojkumar,(Prof.) Dr. Maurvi Vasavada \& Dhruv Nitinbhai Muliya/ Page 634-655

\begin{tabular}{|c|c|c|c|}
\hline Packaging - Packaging on purchase behavior & 412 & 4.0437 & 1.03140 \\
\hline Packaging - Clear information package & 412 & 4.4660 & .74892 \\
\hline Quantity-Offer good quantity & 412 & 4.3689 & .75764 \\
\hline Quantity - Quantity is main factor & 412 & 4.0655 & .95804 \\
\hline Quantity - More quantity in single package & 412 & 3.9515 & 1.00004 \\
\hline Health - Immunity booster & 412 & 4.2039 & .84989 \\
\hline Health - Health conscious & 412 & 4.2573 & .86950 \\
\hline Health - Conscious about immunity & 412 & 4.3422 & .77796 \\
\hline Advertisement - Attractive advertisement & 412 & 4.0947 & .90324 \\
\hline Advertisement - Awareness through advertisement & 412 & 4.0995 & .90540 \\
\hline Advertisement - Attractive advertisement brand recognition & 412 & 4.1723 & .89710 \\
\hline Acceptability - Pleasant taste & 412 & 4.1456 & .89777 \\
\hline Acceptability - Different flavor & 412 & 4.1359 & .86058 \\
\hline Acceptability - Easily acceptable taste & 412 & 4.2985 & .73209 \\
\hline Shelf life - Long expiry date & 412 & 4.2209 & .76559 \\
\hline Shelf life - Long term use & 412 & 4.3398 & .75201 \\
\hline Shelf life - Remain as it is & 412 & 4.2573 & .74600 \\
\hline Wide range - Available in wide range & 412 & 4.3689 & .70439 \\
\hline Wide range - Various physical form & 412 & 4.3131 & .78087 \\
\hline Wide range - Purchase in different quantity & 412 & 4.2330 & .77307 \\
\hline Brand choice - Brand who think more for customer & 412 & 4.4345 & .75974 \\
\hline Brand choice - Customer perspective & 412 & 4.4442 & .71772 \\
\hline Brand choice - Customer centric approach & 412 & 4.3592 & .77810 \\
\hline
\end{tabular}


Towards Excellence: An Indexed, Refereed \& Peer Reviewed Journal of Higher Education Dr. Shah Suraj Manojkumar,(Prof.) Dr. Maurvi Vasavada \& Dhruv Nitinbhai Muliya/ Page 634-655

\begin{tabular}{|l|c|c|c|}
\hline Brand quality approach - Quality conscious brand & 412 & 4.5316 & .66287 \\
\hline Brand quality approach - Brand loyal based on quality & 412 & 4.3374 & .83725 \\
\hline Brand quality approach - Good image for quality & 412 & 4.3641 & .79443 \\
\hline Overall preference & 412 & 4.2646 & .83733 \\
\hline
\end{tabular}

Here the Mean test concluded that the complete mean test is positive in nature that majority of the respondent has positive preference towards Nutraceuticals and dietary supplement.

\section{Analysis and Hypothesis Testing}

H01 $_{1}$ There is no association between gender and consumer preference towards price with reference to nutraceuticals and dietary supplements.

\begin{tabular}{|l|r|r|r|}
\hline & & & \multicolumn{2}{c|}{$\begin{array}{c}\text { Asymp. Sig. (2- } \\
\text { sided) }\end{array}$} \\
\hline Pearson Chi-Square & Value & df & 4 \\
\hline Likelihood Ratio & $25.632^{\mathrm{a}}$ & 4 & .000 \\
\hline Linear-by-Linear Association & 29.259 & 1 & .000 \\
\hline N of Valid Cases & .044 & & .835 \\
\hline
\end{tabular}

Here the significance level is 0.000 , which is less than 0.05 so, we do not accept Null Hypothesis (H0) and we accept Alternative Hypothesis (H1). There is association between gender and consumer preference towards price with reference to nutraceuticals and dietary supplements.

$\mathbf{H O}_{2}=$ There is no significant difference between income and consumer preference towards brand with reference to nutraceuticals and dietary supplements.

\begin{tabular}{|l|l|r|r|r|r|r|}
\hline \multicolumn{2}{|l|}{} & \multicolumn{1}{|c|}{$\begin{array}{c}\text { Sum of } \\
\text { Squares }\end{array}$} & df & \multicolumn{1}{c|}{$\begin{array}{c}\text { Sean } \\
\text { Square }\end{array}$} & F & Sig. \\
\hline $\begin{array}{l}\text { I would prefer the } \\
\text { brand who think } \\
\text { more for customer }\end{array}$ & $\begin{array}{l}\text { Between } \\
\text { Groups }\end{array}$ & 15.311 & 6 & 3.062 & 5.602 & .000 \\
\cline { 2 - 8 } & Within Groups & 221.919 & 406 & .547 & & \\
\cline { 2 - 8 } & Total & 237.231 & 412 & & & \\
\hline $\begin{array}{l}\text { The brand should } \\
\text { always make } \\
\text { products from }\end{array}$ & $\begin{array}{l}\text { Between } \\
\text { Groups }\end{array}$ & 7.213 & 6 & 1.443 & 2.864 & .015 \\
\cline { 2 - 8 } & Within Groups & 204.503 & 406 & .504 & & \\
\hline
\end{tabular}


Towards Excellence: An Indexed, Refereed \& Peer Reviewed Journal of Higher Education Dr. Shah Suraj Manojkumar,(Prof.) Dr. Maurvi Vasavada \& Dhruv Nitinbhai Muliya/ Page $\underline{634-655}$

\begin{tabular}{|c|c|c|c|c|c|c|}
\hline $\begin{array}{l}\text { customers } \\
\text { perspective }\end{array}$ & Total & 211.716 & 412 & & & \\
\hline \multirow{3}{*}{$\begin{array}{l}\text { The brand should } \\
\text { have customer } \\
\text { centric approach }\end{array}$} & $\begin{array}{l}\text { Between } \\
\text { Groups }\end{array}$ & 17.856 & 6 & 3.571 & 6.277 & .000 \\
\hline & Within Groups & 230.979 & 406 & .569 & & \\
\hline & Total & 248.835 & 412 & & & \\
\hline \multirow{3}{*}{$\begin{array}{l}\text { I would prefer the } \\
\text { brand Which is more } \\
\text { Quality conscious. }\end{array}$} & $\begin{array}{l}\text { Between } \\
\text { Groups }\end{array}$ & 12.410 & 6 & 2.482 & 5.992 & .000 \\
\hline & Within Groups & 168.180 & 406 & .414 & & \\
\hline & Total & 180.590 & 412 & & & \\
\hline \multirow{3}{*}{$\begin{array}{l}\text { I am that type of } \\
\text { person who is loyal } \\
\text { to the brand for the } \\
\text { quality }\end{array}$} & $\begin{array}{l}\text { Between } \\
\text { Groups }\end{array}$ & 28.445 & 6 & 5.689 & 8.895 & .000 \\
\hline & Within Groups & 259.659 & 406 & .640 & & \\
\hline & Total & 288.104 & 412 & & & \\
\hline \multirow{3}{*}{$\begin{array}{l}\text { The brand should } \\
\text { have good image for } \\
\text { the quality parameter }\end{array}$} & $\begin{array}{l}\text { Between } \\
\text { Groups }\end{array}$ & 26.165 & 6 & 5.233 & 9.110 & .000 \\
\hline & Within Groups & 233.223 & 406 & .574 & & \\
\hline & Total & 259.388 & 412 & & & \\
\hline
\end{tabular}

In this data analysis the significant value at confidence level respectively at $95 \%$, is $0.000,0.015,0.000,0.000,0.000,0.000$ which is not more than 0.05 so here null hypothesis (HO) is not accepted and alternative hypothesis (H1) is accepted so there is difference between income and their preference towards brand.

H03 $=$ There is no significant difference between awareness and consumerpreference with reference to nutraceuticals and dietary supplements.

\begin{tabular}{|l|r|r|r|r|r|}
\hline ANOVA & \multicolumn{1}{|c|}{$\begin{array}{c}\text { Sum of } \\
\text { Squares }\end{array}$} & df & Mean Square & F & \multicolumn{1}{c|}{ Sig. } \\
\hline Between Groups & 3.500 & 1 & 3.500 & 5.041 & .025 \\
\hline Within Groups & 284.662 & 411 & .694 & & \\
\hline Total & 288.163 & 412 & & & \\
\hline
\end{tabular}

Here the Significant value at confidence level at $95 \%$ is 0.025 , which is not more than 0.05 so here null hypothesis (HO) is not accepted and alternative hypothesis (H1) is accepted so there is significance difference between awareness and their strong preference.

$\mathrm{HO}_{4}=$ There is no significant difference between Consumer's preference of product in terms of price and income with reference to nutraceuticals and dietary supplements. 
Towards Excellence: An Indexed, Refereed \& Peer Reviewed Journal of Higher Education Dr. Shah Suraj Manojkumar,(Prof.) Dr. Maurvi Vasavada \& Dhruv Nitinbhai Muliya/ Page 634-655

\begin{tabular}{|l|r|r|r|r|r|}
\hline & \multicolumn{1}{|c|}{$\begin{array}{c}\text { Sum of } \\
\text { Squares }\end{array}$} & Df & Mean Square & F & Sig. \\
\hline Between Groups & 20.662 & 6 & 4.132 & 3.931 & .002 \\
\hline Within Groups & 426.821 & 406 & 1.051 & & \\
\hline Total & 447.483 & 412 & & & \\
\hline
\end{tabular}

Here the significance level is 0.002 , which is less than 0.05 so, we do not accept Null Hypothesis (H0) and we accept Alternative Hypothesis (H1). There is association between their preference of product in terms of price and income.

$\mathbf{H O}_{5}=$ There is no significant difference between education and preference about quality product with reference to nutraceuticals and dietary supplements.

\begin{tabular}{|l|r|r|r|r|r|}
\hline & \multicolumn{1}{|c|}{$\begin{array}{c}\text { Sum of } \\
\text { Squares }\end{array}$} & Df & Mean Square & F & Sig. \\
\hline Between Groups & 6.343 & 6 & 1.586 & 2.833 & .024 \\
\hline Within Groups & 227.205 & 406 & .560 & & \\
\hline Total & 233.547 & 412 & & & \\
\hline
\end{tabular}

Here the significance level is 0.024 , Which is less than 0.05 so, we do not accept Null Hypothesis (H0) and we accept Alternative Hypothesis (H1). There is association between education and their preference about quality product.

H06 $=$ There is no significant difference between consciousness towards immunity and preference during and after covid-19 pandemic with reference to nutraceuticals and dietary supplements.

\begin{tabular}{|l|r|r|r|r|r|}
\hline & \multicolumn{1}{|c|}{$\begin{array}{l}\text { Sum of } \\
\text { Squares }\end{array}$} & Df & Mean Square & F & Sig. \\
\hline Between Groups & 59.511 & 1 & 59.511 & 102.795 & .000 \\
\hline Within Groups & 237.362 & 411 & .579 & & \\
\hline Total & 296.874 & 412 & & & \\
\hline
\end{tabular}

Here the significance level is 0.000 , Which is less than 0.05 so, we do not accept Null Hypothesis (H0) and we accept Alternative Hypothesis (H1). There is association between consciousness towards immunity and preference during and after covid-19 pandemic.

$\mathbf{H 0}_{7}=$ There is no significant difference between among education and perception regarding consciousness towards their immunity with reference to nutraceutical and dietary supplements.

\section{Multivariate Tests ${ }^{\mathrm{a}}$}


Towards Excellence: An Indexed, Refereed \& Peer Reviewed Journal of Higher Education Dr. Shah Suraj Manojkumar,(Prof.) Dr. Maurvi Vasavada \& Dhruv Nitinbhai Muliya/ Page 634-655

\begin{tabular}{|c|c|c|c|c|c|c|}
\hline \multicolumn{2}{|l|}{ Effect } & Value & $\mathrm{F}$ & $\begin{array}{c}\text { Hypothesis } \\
\text { df }\end{array}$ & $\begin{array}{c}\text { Error } \\
\text { df }\end{array}$ & Sig. \\
\hline \multirow[t]{4}{*}{$\begin{array}{l}\text { Educatio } \\
\mathrm{n}\end{array}$} & Pillai's Trace & .045 & 2.357 & 8.000 & $\begin{array}{r}814.00 \\
0\end{array}$ & .017 \\
\hline & Wilks' Lambda & .955 & $2.356^{\mathrm{b}}$ & 8.000 & $\begin{array}{r}812.00 \\
0\end{array}$ & .017 \\
\hline & Hotelling's Trace & .047 & 2.356 & 8.000 & $\begin{array}{r}810.00 \\
0\end{array}$ & .017 \\
\hline & $\begin{array}{l}\text { Roy's Largest } \\
\text { Root }\end{array}$ & .034 & $3.429^{c}$ & 4.000 & $\begin{array}{r}407.00 \\
0\end{array}$ & .009 \\
\hline \multicolumn{7}{|c|}{ a. Design: Intercept + Education } \\
\hline \multicolumn{7}{|c|}{ b. Exact statistic } \\
\hline
\end{tabular}

Here P value for the multivariate assessments namely Pillai's Trace test, Wilks' Lambda \& Hötelling's Trace tests and Roy's Largest Root test have shown in the above table that is less than 0.05 with the F value of respectively $2.357,2.356,2.356$ and 3.429.

The P value of MANOVA test is 0.017 and 0.009 which is less than the significant value so here we reject a null hypothesis. It can also be determined that there is a significant difference among education and perception regarding consciousness towards their immunity.

\begin{tabular}{|l|l|r|r|r|r|r|}
\hline \multicolumn{7}{|c|}{ Tests of Between-Subjects Effects } \\
\hline \multirow{2}{*}{ Source } & $\begin{array}{l}\text { Type III } \\
\text { Sum of } \\
\text { Squares }\end{array}$ & df & $\begin{array}{c}\text { Mean } \\
\text { Square }\end{array}$ & F & Sig. \\
\hline Education & $\begin{array}{l}\text { Health - Health } \\
\text { conscious }\end{array}$ & 7.684 & 4 & 1.921 & 2.580 & .037 \\
\cline { 2 - 8 } & $\begin{array}{l}\text { Health - Conscious } \\
\text { about immunity }\end{array}$ & 7.611 & 4 & 1.903 & 3.212 & .013 \\
\hline
\end{tabular}

Here tests of Between the Subject Effects show the result of an individual ANOVA for two statement consciousness towards their health and immunity which reveals that $\mathrm{P}$ values varies between 0.013 to 0.037 . Individual ANOVA conclude that education has the significant impact on health consciousness of people and it conclude that mean value of different education categories for consciousness towards their health and immunity are different.

Mean value table also indicates that the mean value is significantly different for all education categories both two statements. High education is having more positive effect on consciousness towards health and immunity compare to lower education.

H08 $=$ There is no significant difference between among family annual income and perception regarding Price of the product with reference to nutraceuticals and dietary supplements. 
Towards Excellence: An Indexed, Refereed \& Peer Reviewed Journal of Higher Education DDr. Shah Suraj Manojkumar,(Prof.) Dr. Maurvi Vasavada \& Dhruv Nitinbhai Muliya/ Page 634-655

\begin{tabular}{|c|c|c|c|c|c|c|}
\hline \multicolumn{7}{|c|}{$\begin{array}{c}\text { MANOVA } \\
\text { Multivariate Tests }^{\mathrm{a}}\end{array}$} \\
\hline \multicolumn{2}{|l|}{ Effect } & Value & $\mathrm{F}$ & $\begin{array}{l}\text { Hypothesi } \\
\text { s df }\end{array}$ & $\begin{array}{c}\text { Error } \\
\text { df }\end{array}$ & Sig. \\
\hline \multirow{4}{*}{$\begin{array}{l}\text { Annual } \\
\text { Family } \\
\text { Income }\end{array}$} & Pillai's Trace & .164 & 2.755 & 25.000 & $\begin{array}{r}2030.0 \\
00\end{array}$ & .000 \\
\hline & Wilks' Lambda & .844 & 2.801 & 25.000 & $\begin{array}{r}1494.8 \\
66\end{array}$ & .000 \\
\hline & $\begin{array}{l}\text { Hotelling's } \\
\text { Trace }\end{array}$ & .176 & 2.825 & 25.000 & $\begin{array}{r}2002.0 \\
00\end{array}$ & .000 \\
\hline & $\begin{array}{l}\text { Roy's Largest } \\
\text { Root }\end{array}$ & .093 & $7.560^{c}$ & 5.000 & $\begin{array}{r}406.00 \\
0\end{array}$ & .000 \\
\hline
\end{tabular}

Here P value for the multivariate assessments namely Pillai's Trace test, Wilks' Lambda \& Hötelling's Trace tests and Roy's Largest Root test have shown in the above table that is less than 0.05 with the $F$ value of respectively $2.755,2.801,2.825$ and 7.560.

The $\mathrm{P}$ value of MANOVA test is 0.000 which is less than the significant value so here we reject a null hypothesis. It can also be determined that there is a significant difference among family annual income and perception regarding Price of the product.

\begin{tabular}{|c|c|c|c|c|c|c|}
\hline \multicolumn{7}{|c|}{ Tests of Between-Subjects Effects } \\
\hline Source & $\begin{array}{l}\text { Dependent } \\
\text { Variable }\end{array}$ & $\begin{array}{l}\text { Type III } \\
\text { Sum of } \\
\text { Squares }\end{array}$ & df & $\begin{array}{l}\text { Mean } \\
\text { Square }\end{array}$ & $\mathrm{F}$ & Sig. \\
\hline \multirow[t]{4}{*}{$\begin{array}{l}\text { AnnualFamilyI } \\
\text { ncome }\end{array}$} & $\begin{array}{l}\text { Price - Affordable } \\
\text { price }\end{array}$ & 6.883 & 5 & 1.377 & 1.618 & .154 \\
\hline & $\begin{array}{l}\text { Price - Rate } \\
\text { product in terms of } \\
\text { price }\end{array}$ & 20.662 & 5 & 4.132 & 3.931 & .002 \\
\hline & $\begin{array}{l}\text { Price - Inexpensive } \\
\text { product }\end{array}$ & 28.862 & 5 & 5.772 & 4.547 & .000 \\
\hline & $\begin{array}{l}\text { Price - Value for } \\
\text { money }\end{array}$ & 27.964 & 5 & 5.593 & 6.015 & .000 \\
\hline
\end{tabular}


Towards Excellence: An Indexed, Refereed \& Peer Reviewed Journal of Higher Education Dr. Shah Suraj Manojkumar,(Prof.) Dr. Maurvi Vasavada \& Dhruv Nitinbhai Muliya/ Page 634-655

\begin{tabular}{|l|l|l|l|l|l|l|}
\hline & $\begin{array}{l}\text { Price - Conscious } \\
\text { towards low price }\end{array}$ & 30.612 & 5 & 6.122 & 4.355 & .001 \\
\hline
\end{tabular}

Here tests of Between the Subject Effects show the result of an individual ANOVA for all five Price of the product which reveals that $P$ values varies between $0.000-0.154$. Individual ANOVA conclude that a significant difference between among family annual income and perception regarding Price of the product with reference to nutraceuticals and dietary supplements.

Mean value table also indicates that the mean value is significantly different for all the annual income categories all five statements. High family income is having more positive effect on Price of the product compare to lower family income.

$\mathbf{H O 9}_{\mathbf{9}}=$ There is no significant impact of consumer preference on consciousness towards immunity with reference to nutraceuticals and dietary supplements.

Regression Analysis

ANOVA ${ }^{\mathrm{a}}$

\begin{tabular}{|l|l|r|r|r|r|c|}
\hline \multicolumn{2}{|l|}{ Model } & \multicolumn{1}{c|}{$\begin{array}{c}\text { Sum of } \\
\text { Squares }\end{array}$} & Df & Mean Square & F & \multicolumn{1}{c|}{ Sig. } \\
\hline \multirow{3}{*}{1} & Regression & 44.860 & 1 & 44.860 & 90.210 & $.000^{\mathrm{b}}$ \\
\cline { 2 - 7 } & Residual & 203.885 & 411 & .497 & & \\
\cline { 2 - 7 } & Total & 248.745 & 412 & & & \\
\hline
\end{tabular}

This resulted table designates that regression model forecasts the dependent variable significantly well. This shows the statistical significance of the regression model that was run. This point, $\mathrm{p}$ of $\mathrm{f}$ test value is 0.00 , which is under 0.05 , and designates that, the model of regression statistically suggestively forecasts the result variable.

\section{Coefficients ${ }^{\mathrm{a}}$}

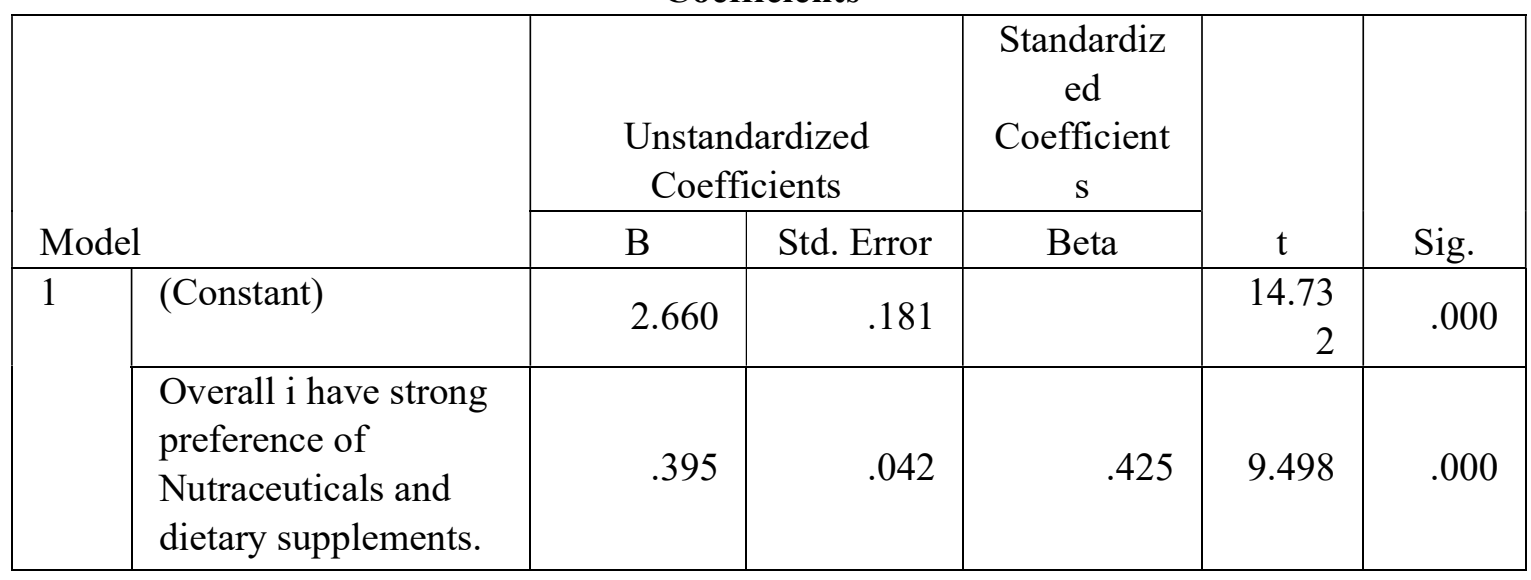

According to the Coefficients, having a 0.000 as a significance level, It rejects a null hypothesis and concludes a significant impact of consumer preference on consciousness towards immunity.

\section{Finding and Discussion}


Towards Excellence: An Indexed, Refereed \& Peer Reviewed Journal of Higher Education Dr. Shah Suraj Manojkumar,(Prof.) Dr. Maurvi Vasavada \& Dhruv Nitinbhai Muliya/ Page $\underline{634-655}$

- From the total 412 respondents, $66.7 \%$ respondents were male in numeric 283 and 31.7 $\%$ were female in numeric 129.

- There are five categories of age group with 412 respondents, 98 respondents were belonging to age group of $18-28$ which is $23.78 \%, 93$ respondents belonging to age group 29-38 which is $22.57 \%, 81$ respondents were belonging to age group 39-48 which is $19.66 \%, 92$ respondents were belonging to age group of $49-58$ which is $22.33 \%$ and 48 respondents were belonging to above 58 years category which is $11.66 \%$.

- $79.13 \%$ respondents are married and remaining are unmarried $(20.87 \%)$. From the education perspective, Majority of respondents are Graduate or Post graduate $(81.8 \% \%)$. As far as occupation is concerned, Majority of respondents are having either business $(27.1 \%)$, or they are salaried (26.21\%). Majority of respondents have 3-4 family members in household (60.2\%). Majority of the respondents have annual family income above 2 Lacks (78.88\%).

- $34 \%$ respondents got information about Nutraceuticals and dietary supplements from doctors which indicates doctors respondents to get information about Nutraceuticals and dietary supplements.

- $76.2 \%$ respondents prefer Nutraceuticals and dietary supplements as self-medication.

- $40.29 \%$ respondents prefer the Nutraceuticals and dietary supplements in Liquid form, while rest prefer Nutraceuticals in other forms such as powder, Tablet/capsule and sachet.

- $85.4 \%$ respondents prefer Nutraceuticals and dietary supplements during and after Covid-19 pandemic.

- $48.5 \%$ respondents prefer Nutraceuticals and dietary supplements as an Individual and $51.5 \%$ respondents prefer Nutraceuticals and dietary supplements in Combination.

- Cronbach's alpha value is 0.950 which indicates very high reliability for collected data.

- Data analysis suggest that association between gender and consumer preference towards price with reference to nutraceuticals and dietary supplements.

- Analysis of Variance (ANOVA) test conclude that significance difference between income and consumer preference towards brand with reference to nutraceuticals and dietary supplements. 
Towards Excellence: An Indexed, Refereed \& Peer Reviewed Journal of Higher Education Dr. Shah Suraj Manojkumar,(Prof.) Dr. Maurvi Vasavada \& Dhruv Nitinbhai Muliya/ Page $\underline{634-655}$

- Awareness toward products plays vital role for marketer and Analysis of Variance study suggest that significance difference between awareness and consumer preference with reference to nutraceuticals and dietary supplements.

- Price has significant effect on consumer and data analysis conclude that association between Consumer's preference of product in terms of price and income with reference to nutraceuticals and dietary supplements.

- Study suggest that the education of people influence the buyer's preference towards quality product as per data analysis.

- The consciousness towards immunity people effect on preference of people during and after covid-19 pandemic.

- There is significant impact of consumer preference on consciousness towards immunity with reference to nutraceuticals and dietary supplements.

- Multivariate Analysis of Variance (MANOVA) study concludes a significant difference between among family annual income and perception regarding Price of the product additionally it has also been found that is a significant difference among education and perception regarding consciousness towards their immunity.

\section{Managerial Implication}

- This report study is very beneficial to the society and marketers by this study they can give more concentration on factors like Quality, price, brand which makes signification impact and contribute on consumer preference. Also, the demographic statistics gives vital information for marketers for product development and marketing aspects.

- Awareness plays vital role for grow a product here also the study suggests that awareness towards nutraceutical and dietary supplements and health consciousness of people towards health and their immunity can make major impact for product purchasing. Marketers have to focus on increase awareness of nutraceuticals and dietary supplements and also regarding awareness of health which will makes drastically increase in sales.

- As the regression study suggest that people are more conscious about health, they prefer more nutraceuticals and dietary supplements because it focused on health benefits. Health-conscious people can target first. Marketers also can create the awareness among the people towards their health consciousness. 
Towards Excellence: An Indexed, Refereed \& Peer Reviewed Journal of Higher Education Dr. Shah Suraj Manojkumar,(Prof.) Dr. Maurvi Vasavada \& Dhruv Nitinbhai Muliya/ Page $\underline{634-655}$

- $76.2 \%$ respondents are preferring nutraceuticals and dietary supplements as a selfmedication accordingly marketers can target the large population.

- $34 \%$ respondent's source of information is doctors therefore marketers have to make doctors aware so they can suggest to their patients. As the nutraceuticals product does not require the prescription of doctor but when doctor suggest than the quality and result of product could lead a positive perceptual effect on consumer.

\section{Conclusion}

The research study was focusing on objectives 1) To study preference of consumers for the Nutraceuticals dietary supplements. The study concludes that $80.5 \%$ people are prefer nutraceutical and dietary supplements product as their health supplements to improve their health. 2) To know the health consciousness of the people. The study concludes, The health consciousness makes strong impact on preference of people that prefer more nutraceuticals and dietary supplements as these product concentrate on health of a society. The health consciousness of people is $82.8 \%$. 3) To study the awareness level of people towards Nutraceuticals dietary supplements. By the study came to know that $100 \%$ people on which the study conducted they are aware about nutraceuticals and dietary supplements. The study also concludes a significant impact of consumer preference on consciousness towards immunity with reference to nutraceuticals and dietary supplements.

\section{Future Scope of Study}

Further study can be conducted across different states of India, with more sample size and outcome can be validated with statistical soft wares like AMOS or R. 
Towards Excellence: An Indexed, Refereed \& Peer Reviewed Journal of Higher Education Dr. Shah Suraj Manojkumar,(Prof.) Dr. Maurvi Vasavada \& Dhruv Nitinbhai Muliya/ Page $\underline{634-655}$

\section{Works Cited}

Ahmad A. Abdul-Aziz, P. D. (2019). Cardiovascular Quality and outcome. AHA journals. bahadoran, Z., mirmiran, P., \& azizi, F. (2013). Dietary polyphenols as potential nutraceutocals in management of diabetes : a review. Journal od diabetes \& metabolic disorders, 1-9.

Bajtelsmit, V. a. (1996). Why do women invest differently than men? Association for Financial Counseling and Planning Education, 1-10.

Banerjee, S. (2018). Dietary supplements market in india is rapidly growing-An overview. $1-10$.

barnes, S., \& prasain, J. (2005). Current progress in the use of trditional medicines and nutraceuticals. 324-328.

Basak, A. (2011). PROBLEMS AND PROSPECTS OF NUTRACEUTICAL MARKETING IN INDIA (A study with reference to Maharashtra \& Andhra Pradesh). 1185.

basu, S. K., thomas, J. E., \& acharya, S. N. (2007). Prospects for growth in global nutraceutical and functional food markets: A Canadian Perspective. 637-649.

bull, E., rapport, L., \& lockwood, B. (2000). What is nutraceutical?

Cardello.Armand, \& Schutz, H. (2003). The Importance of Taste and other Product Factors to Consumer interest in Nutraceutical Products: Civilian and Military Comparison. Journal of Food Science, 1519-1524.

chaudhari, S. P., power, P. V., \& pratapwar, M. N. (2017). Nutraceuticals : A review. World journal of pharmacy and pharmaceutical science, 681-739.

cicero, A. F., \& colletti, A. (2017). Nutraceuticals and Dietary Supplements to Improve Quality of Life and Outcomes in. 1-8.

das, L., bhaumik, E., raychaudhuri, U., \& chakraborty, R. (2011). Role of nutraceuticals in human health. 173-183.

dureja, H., kaushik, D., \& kumar, V. (2003). Developments in Nutraceuticals. 363-372.

fardet, A. (2015). Complex foods versus functional foods, Nutraceuticals and dietary supplements: Different health impact. 20-24.

gupta, C., \& prakash, D. (2014). Nutraceuticals for geriatrics. Journal of traditional and complementary medicine, 5-14. 
Towards Excellence: An Indexed, Refereed \& Peer Reviewed Journal of Higher Education Dr. Shah Suraj Manojkumar,(Prof.) Dr. Maurvi Vasavada \& Dhruv Nitinbhai Muliya/ Page $\underline{634-655}$

Gupta, S., chauhan, D., mehla, K., sood, P., \& nair, A. (2010). AN OVERVIEW OF NUTRACEUTICALS : CURRENT SCENARIO. 55-62.

jain, N., \& ramawat, K. G. (2013). Nutraceuticals and Antioxidants in prevention of disease. 2559-2580.

kalra, E. K. (2003). Nutraceutical - Definition and Introducrion. 1-2.

Keservani, R. K., Kesherwani, R. K., vyas, N., jain, S., raghuvanshi, R., \& Sharma, A. K. (2010). Nutraceutical and functional food as future food: A review. 106-116.

Kotecha, P. V. (2008). Micronutrient malnutrition in India. Indian Journal of Community Medicine.

laturkar, D. (2011). PROBLEMS AND PROSPECTS OF NUTRACEUTICAL MARKETING IN INDIA (A study with reference to maharashtra \& andhra pradesh). 1185.

Maughan, R. J., King, D. S., \& Lea, T. (2003). Dietary supplement.

Mehta, J., \& Huynh-ba, K. (2010). Practical challenges of stability testing of nutraceutical formulation. 1-11.

Mishra, A. R. (2018). DEVELOPMENT AND EVALUATION OF DIETARY SUPPLEMENT FOR DIABETICS. 1-407.

nasri, H., baradaran, A., shirzad, H., \& kopaei, M. r. (2014). New concept in Nutraceuticals as alternative for pharmaceuticals. 1487-1499.

Pandey, M., verma, R. K., \& saraf, S. A. (2010). Nutraceuticals: New era of medicine and health. 11-15.

prabhu, S. L., SuriyaPrakash, T., kumar, C. D., kumar, S. S., \& Raghavendran, T. (2012). Nutraceuticals: A review. 8372-8377.

R.venkataraman, D. (2011). Studies on Nutraceuticals. 1-215.

radhika, P. r., rawat, B. m., \& thangavel, S. (n.d.). Neutraceuticals: An Area of Tremendous Scope.

rajasekaran, A., sivagnanam, G., \& xavier, R. (2008). Nutraceuticals as therapeutic agents: A Review. 328-340.

shahidi, F. (2012). Nutraceuticals, Functional Foods and Dietary Supplements in health disease. 226-230.

sharma, R. (2017). Indian Nutraceuticals industry Current scenario \& future trends. 11-60. shinde, N., bangar, B., deshmukh, S., \& kumbhar, P. (2014). Nutraceuticals : A review on current status. 110-113. 
Towards Excellence: An Indexed, Refereed \& Peer Reviewed Journal of Higher Education Dr. Shah Suraj Manojkumar,(Prof.) Dr. Maurvi Vasavada \& Dhruv Nitinbhai Muliya/ Page $\underline{634-655}$

Sohaimy, S. E. (2012). Functional Foods and Nutraceuticals-Modern Approach to Food Science. World applied science journal, 691-708.

souyoul, S. A., saussy, K. P., P, M., \& lupo. (2017). Nutraceutical: A review. 5-16.

Teoh, S. L., Ngorsuraches, S., Ming Lai, n., Bangpan, M., \& Chaiyakunapruk, N. (2018).

Factors affecting consumers' decisions on the use of nutraceuticals:a systemic review.

International Journal of Food Sciences and Nutrition, 1-22.

TimeMagazine. (2003). The Coming Epidemic Of Arthritis. Time Magazine.

Wadekar, K. (2009). Entry strategy for Nutraceuticals Market in India. 1-219.

(2009). World Health Statistics 2009. WHO.

WorldBank. (2007). World Development Indicators 2007. World Bank.

$<$ https:/www.bmw.in/en/topics/owners/bmw-apps/virtual-and-augmented-reality.html>.

Bonetti, Francesca, Gary Warnaby and Lee Quinn. Augmented Reality and Virtual Reality in Physical and Online Retailing: A Review, Synthesis and Research Agenda. Springer, 2017.

Charlotte Yianni. 3 WAYS AUGMENTED REALITY POWERFULLY ENHANCES PRINT CAMPAIGNS. 2703 2018. 0710 2019. <https://www.blippar.com/blog/2018/03/27/3ways-augmented-reality-powerfully-enhances-print-campaigns $>$.

Freeman, D., et al. "Virtual reality in the assessment, understanding, and treatment of mental health disorders." Psychological Medicine (2017): 2393-2400.

Google. Introducing Live View, the new augmented reality feature in Google Maps. 0809 2019. 0610 2019. <https://support.google.com/maps/thread/11554255?hl=en>.

Griffin, Tom, et al. "Virtual Reality and Implications for Destination." 48th Annual Travel and Tourism Research Association (TTRA). Travel and Tourism Research Association, 2017.

Lin, Jih-Hsuan Tammy and Chen-Chao Tao. "So scary, yet so fun: The role of self-efficacy in enjoyment of a virtual reality horror game." New Media \& Society (2017).

Merchant, Zahira, et al. "Effectiveness of virtual reality-based instruction on students' learning outcomes in K-12 and higher education: A meta-analysis." Computers \& Education (2014): 29-40.

Tata ELXSI. Augmented and Virtual Reality: Helping Tata Motors to provide an immersive automotive experience at the Geneva Motor Show. 2016. 05102019. $<$ https://tataelxsi.com/industries/automotive/visualization-digital-marketing/ar-vr.html $>$.

Yariv Levski. Augmented Reality. 2019. $07 \quad 10 \quad 2019 . \quad<$ https://apprealvr.com/blog/augmented-reality-car-repair/>. 


\author{
Dr. Shah Suraj Manojkumar \\ Assistant Professor, \\ Ganpat University-Centre for Management Studies and Research \\ Kherva, Mehsana \\ sms01@ganpatuniversity.ac.in, M. 9099537372 \\ \& \\ (Prof.) Dr. Maurvi Vasavada \\ Professor and Head, Chairperson, \\ Ganpat University-Centre for Management Studies and Research \\ Kherva, Mehsana. \\ chairperson.cms@ganpatuniversity.ac.in, M. 9979050918 \\ \& \\ Dhruv Nitinbhai Muliya \\ Student, MBA Pharmaceuticals, \\ Ganpat University-Centre for Management Studies and Research \\ Kherva, Mehsana. \\ dhruv.muliya111@gmail.com,M.7817813006
}

